\title{
Three-Dimensional Magnetic Motion Capture Using Four Square Coils
}

\author{
T. Yamaguchi, H. Kashima, and I. Sasada* \\ Interdisciplinary Graduate School of Engineering Sciences, Kyushu Univ., 6-1 Kasuga-kōen, Kasuga-shi, Fukuoka 816-8580, Japan \\ *Faculty of Engineering Sciences, Kyushu Univ., 6-1 Kasuga-kōen, Kasuga-shi, Fukuoka 816-8580, Japan
}

\begin{abstract}
A new magnetic method of motion capture is proposed. To produce reference magnetic fields, this method uses a simple coil system which consists of two pairs of square coils, which are placed along the sides of two sets of opposite surfaces of a cubic frame where one pair of the coils is rotated through 90 degrees from the other. Two quasi-uniform magnetic fields and one gradient magnetic field are successively generated by these coils and are measured by a triaxial magnetic sensor attached to the moving object. The coordinates of the object are calculated by the Gauss-Newton method from several scalar functions defined by scalar products of the measured magnetic field vectors. The effective area where motion capture can be stably performed was numerically estimated to be a little larger than a cubic area with an edge length of 60 percent of that of the cubic frame.
\end{abstract}

Key words: magnetic motion capture, triaxial magnetic sensor, square coil, scalar product, nonlinear least squares problem, GaussNewton method

\section{4 個の正方形コイルを用いた 3 次元磁気式モーションキャプチャ}

\author{
山口 崇, 加嶋良年, 笹田一郎* \\ 九州大学大学院総合理工学府, 福岡県春日市春日公園 6-1 (广816-8580) \\ * 九州大学大学院総合理工学研究院, 福岡県春日市春日公園 6-1（T816-8580）
}

\section{1 はじめに}

モーションキャプチャあるいはモーショントラッキングと呼 ばれる，3 次元空間において物体の位置および姿勢を計測する 技術は，人体の動きを計測する目的で広く利用されている．原 理としては主に, 光学式, 磁気式, 超音波式などが用いられて いる ${ }^{1,2)}$.

磁気式のシステムは通常, 位置および姿勢の基準となる参照 磁界の発生源と, 物体に取り付けられた磁界センサより構成さ れる ${ }^{3,4)}$. 参照磁界源は, 計測空間に設定された全体座標系を 位置および方向の基準として, 計測領域の外部に配置され，そ の磁界は，物体とともに運動する磁界センサにより計測され る. 磁界センサとしては, センサに付随する局所的な直交座標 系の 3 軸についての磁界ベクトル成分を計測できる, 直交 3 軸 磁界センサがよく用いられる。磁界センサの位置および姿勢は 未知であり, 全体座標系における位置座標の関数として既知で ある複数の参照磁界と, それらに対する磁界センサ出力との対 応関係から，何らかの方法により推定する必要がある。

参照磁界としてダイポール磁界を用いる方式については，す でに多くの研究がある ${ }^{3-6)}$. ダイポール磁界は小型のコイルで 容易に発生させることができ，その磁界分布は簡単な数式で計 算することができる，磁界の大きさは発生源からの距離の 3 乗 に逆比例するため, 広い計測領域で位置計測の精度を確保する には, 強い磁界から弱い磁界まで十分な分解能で計測できる, ダイナミックレンジの大きな磁界計測系が必要である。その一 方で, 磁界発生源の数や配置についての自由度は大きく, 計測 領域や目的・用途に応じた設計が可能である ${ }^{4)}$.

ダイポール磁界以外では, 立方体形状の枠に沿って配置され
た, 複数の正方形コイルを用いる方式が研究されている ${ }^{7-9)}$. 計測領域は立方体枠の内部にほぼ限定され, 設計の自由度は大 きくないが，コイルの近傍を除いて磁界の変化が緩やかである ため, ダイナミックレンジのあまり大きくない磁界計測系で も，位置計測の精度を確保することが比較的容易である．正方 形コイルにより生成される磁界分布を正確に計算するには, ダ イポール磁界に比べてかなり複雑な数式によらなければならな い. しかし，適切なコイルの配置と電流の組み合わせにより， 立方体枠の中心部の比較的広い範囲で, 近似的に一様あるいは 線形勾配とみなせる磁界を生成することができ，その場合の近 似計算はダイポール磁界と同程度に簡単である。

Sasada and Morimoto ${ }^{7,8)}$ により提案された方式では，一様性 の高い磁界を発生させるために, 最適な巻数比をもつ 3 個の正 方形コイルを，立方体枠の対向する両端面とその中間に配置す る。これを直交する 2 つ座標軸方向について 1 組ずつ配置 し, 合計 6 個の正方形コイルを用いる。時分割でそれぞれの 軸方向に発生させた一様磁界を直交 3 軸磁界センサで計測し, 簡単な線形計算によりセンサの姿勢を推定することができる. 姿勢の計算においては, 座標軸の直交関係を利用するため, 残 る 1 つの座標軸方向については, 一様磁界の発生は不要となっ ている。つぎに，1 組のコイルについて，両端の 2 個のコイル のみを用いて線形勾配磁界, すなわち磁界ベクトルの 3 軸成 分が，それぞれの座標值に比例する磁界を発生させる。磁界セ ンサによる線形勾配磁界の観測值と，すでに推定された姿勢を 用いて, 簡単な線形計算により磁界センサの位置を推定するこ とができる，近似的に磁界の一様性および線形勾配が成り立つ 領域で，これを完全な一様磁界および線形勾配磁界とみなすこ とにより，簡単な線形計算で高速に姿勢および位置の推定が可 
能であることが，かれらの方式の大きな特長である，その一方 で, コイルが立方体枠の面の中央を横断あるいは交差し, 物体 や人体の移動の妨げになるのが，実用上の難点である.

直交 3 軸磁界センサで計測された参照磁界は, 磁界センサに 付随する局所座標系のベクトル成分として, センサより出力さ れる. ベクトルの大きさや，2 つのベクトルの内積 (スカラー 積) は, 座標系に依存しないスカラーである ${ }^{10)}$ から, 1 組の 参照磁界のすべてを観測する間, センサがある位置と姿勢で静 止しているとみなせるとき, 磁界ベクトルの大きさや，2つの 磁界ベクトルの内積を，センサの局所座標系で評価すれば，そ れらはセンサの姿勢によらず, 全体座標系の位置座標の関数と なる。この性質を利用すれば，まずはじめに位置を推定し，つ ぎに姿勢を推定する計測手法 ${ }^{3)}$ を構成することが可能である 4).その場合, 一様磁界や線形勾配磁界は必ずしも要求されな いから，正方形コイルの個数を減らした計測方式が実現できる 可能性がある。位置および姿勢は非線形の関係式から推定しな ければならず，線形計算のみによる推定が可能な Sasada and Morimoto の方式の利点は失われるが, 計算量の増加を最小限 に抑えることができれば，システム構成の簡略化や利便性の向 上などの利点が大きくなると考元られる。

本論文では, Sasada and Morimoto の方式から中央のコイル を取り除き，正方形コイルを 4 個に減らした位置計測の方法を 提示する. 3 つの参照磁界に対する直交 3 軸磁界センサの出力 から計算される, 磁界ベクトルの内積を用いて定義されたスカ ラ一関数を用いて, 非線形最小 2 乗問題の解として位置を推定 する。このような方法により位置の推定が可能であることを, 計算機シミュレーションにより示す。

\section{2 正方形コイル対による参照磁界およびスカラー関数}

\section{1 準一様磁界および勾配磁界}

3 次元 Euclid 空間に㧍ける直交座標系 $(x, y, z)$ を, 計測空間 の全体座標系とし, $|x| \leq a,|y| \leq a,|z| \leq a$ の領域を包囲する立 方体形状の枠に沿って, Fig. 1 に示すように配置された，一対 の正方形コイル $C_{z}$ を考える. 2 つのコイルの間隔，および正 方形の一辺の長さは $2 a$ とする.

Fig. 1(a) に示すように，コイル対 $C_{z}$ に同じ大きさの電流 $I$ を同じ方向に流すと, $z$ 方向に主成分をもつ磁界 $\boldsymbol{H}_{z}^{\mathrm{u}}$ が得られ る. $x, y, z$ 方向の単位ベクトルを $\boldsymbol{e}_{x}, \boldsymbol{e}_{y}, \boldsymbol{e}_{z}$ として, $\boldsymbol{H}_{z}^{\mathrm{u}}$ を全体 座標系におけるベクトル成分で,

$$
\boldsymbol{H}_{z}^{\mathrm{u}}=H_{z, x}^{\mathrm{u}} \boldsymbol{e}_{x}+H_{z, y}^{\mathrm{u}} \boldsymbol{e}_{y}+H_{z, z}^{\mathrm{u}} \boldsymbol{e}_{z}
$$

と表すとき，それぞれの成分を原点で $x, y, z$ について Taylor 展 開し 2 次の項まで示すと,

$$
\begin{aligned}
H_{z, x}^{\mathrm{u}} & =H_{0}\left(-\frac{5}{6}\left(\frac{z}{a}\right)\left(\frac{x}{a}\right)+\cdots\right) \\
H_{z, y}^{\mathrm{u}} & =H_{0}\left(-\frac{5}{6}\left(\frac{y}{a}\right)\left(\frac{z}{a}\right)+\cdots\right) \\
H_{z, z}^{\mathrm{u}} & =H_{0}\left(1-\frac{5}{12}\left(\frac{x}{a}\right)^{2}-\frac{5}{12}\left(\frac{y}{a}\right)^{2}+\frac{5}{6}\left(\frac{z}{a}\right)^{2}+\cdots\right)
\end{aligned}
$$

となる.ここで, $H_{0}$ は原点における $\boldsymbol{H}_{z}^{\mathrm{u}}$ の大きさで,

$$
H_{0}=\frac{2 I}{\sqrt{3} \pi a}
$$

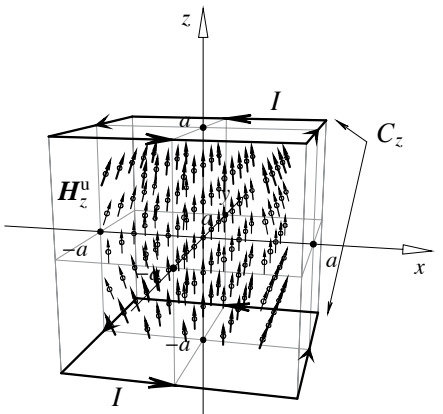

(a) The quasi-uniform magnetic field $\boldsymbol{H}_{z}^{\mathrm{u}}$

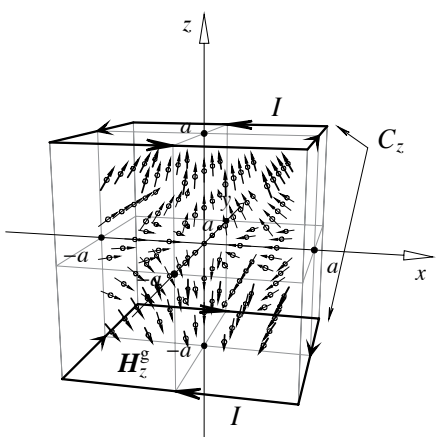

(b) The gradient magnetic field $\boldsymbol{H}_{z}^{\mathrm{g}}$

Fig. 1 The reference magnetic fields generated by a square coil pair $C_{z}$.

である。

式(2)，(3)，(4)より $\boldsymbol{H}_{z}^{\mathrm{u}}$ は原点付近では近似的に,

$$
\boldsymbol{H}_{z}^{\mathrm{u}} \approx H_{0} \boldsymbol{e}_{z}
$$

と表され， $z$ 方向に一様な磁界となる。本論文では $\boldsymbol{H}_{z}^{\mathrm{u}}$ を,$z$ 方 向の準一様磁界と呼ぶことにする.

つぎに, コイル対 $C_{z}$ に, Fig. 1(b) のように電流 $I$ を互いに 逆方向に流して得ら扎る磁界 $\boldsymbol{H}_{z}^{\mathrm{g}}$ を,

$$
\boldsymbol{H}_{z}^{\mathrm{g}}=H_{z, x}^{\mathrm{g}} \boldsymbol{e}_{x}+H_{z, y}^{\mathrm{g}} \boldsymbol{e}_{y}+H_{z, z}^{\mathrm{g}} \boldsymbol{e}_{z}
$$

と表すとき，ベクトル成分のそれぞれを原点において Taylor 展開し 3 次の項まで示すと,

$$
\begin{aligned}
H_{z, x}^{\mathrm{g}} & =-\frac{2}{3} H_{0} \frac{x}{a}\left(1+\frac{5}{72}\left(\frac{x}{a}\right)^{2}-\frac{5}{12}\left(\frac{y}{a}\right)^{2}+\frac{5}{24}\left(\frac{z}{a}\right)^{2}+\cdots\right) \\
H_{z, y}^{\mathrm{g}} & =-\frac{2}{3} H_{0} \frac{y}{a}\left(1-\frac{5}{12}\left(\frac{x}{a}\right)^{2}+\frac{5}{72}\left(\frac{y}{a}\right)^{2}+\frac{5}{24}\left(\frac{z}{a}\right)^{2}+\cdots\right) \\
H_{z, z}^{\mathrm{g}} & =\frac{4}{3} H_{0} \frac{z}{a}\left(1-\frac{5}{48}\left(\frac{x}{a}\right)^{2}-\frac{5}{48}\left(\frac{y}{a}\right)^{2}+\frac{5}{72}\left(\frac{z}{a}\right)^{2}+\cdots\right)
\end{aligned}
$$

となる. 式(8)，(9)，(10)より $\boldsymbol{H}_{z}^{\mathrm{g}}$ は原点付近で近似的に,

$$
\boldsymbol{H}_{z}^{\mathrm{g}} \approx H_{0}\left(-\frac{2}{3} \frac{x}{a} \boldsymbol{e}_{x}-\frac{2}{3} \frac{y}{a} \boldsymbol{e}_{y}+\frac{4}{3} \frac{z}{a} \boldsymbol{e}_{z}\right)
$$

と表され， $x, y, z$ 成分のそれぞれが $x, y, z$ 座標に比例するよう な，線形勾配磁界とみなすことができる，本論文では， $\boldsymbol{H}_{z}^{\mathrm{g}}$ 勾配磁界と呼ぶことにする。 


\section{2 内積によるスカラー関数の構成}

2 つの磁界ベクトル $\boldsymbol{H}_{z}^{\mathrm{u}}, \boldsymbol{H}_{z}^{\mathrm{g}}$ の大きさをそれぞれ $\left|\boldsymbol{H}_{z}^{\mathrm{u}}\right|,\left|\boldsymbol{H}_{z}^{\mathrm{g}}\right|$, なす角を $\theta$ で表すとき, これらのべクトルの内積 (スカラー積) $\left\langle\boldsymbol{H}_{z}^{\mathrm{u}}, \boldsymbol{H}_{z}^{\mathrm{g}}\right\rangle$ は,

$$
\left\langle\boldsymbol{H}_{z}^{\mathrm{u}}, \boldsymbol{H}_{z}^{\mathrm{g}}\right\rangle=\left|\boldsymbol{H}_{z}^{\mathrm{u}}\right|\left|\boldsymbol{H}_{z}^{\mathrm{g}}\right| \cos \theta
$$

で表される。これはまた, 式(1), (7) のベクトル成分を用いて,

$$
\left\langle\boldsymbol{H}_{z}^{\mathrm{u}}, \boldsymbol{H}_{z}^{\mathrm{g}}\right\rangle=H_{z, x}^{\mathrm{u}} H_{z, x}^{\mathrm{g}}+H_{z, y}^{\mathrm{u}} H_{z, y}^{\mathrm{g}}+H_{z, z}^{\mathrm{u}} H_{z, z}^{\mathrm{g}}
$$

と表される。それぞれのベクトル成分は, 式 (2), (3), (4) および 式 (8)，(9)，(10)より， $a$ で規格化された座標值 $x / a, y / a, z / a$ の 関数とみなせるから, 式(13) より, 任意の点において $\left\langle\boldsymbol{H}_{z}^{\mathrm{u}}, \boldsymbol{H}_{z}^{\mathrm{g}}\right\rangle$ は, $x / a, y / a, z / a$ の関数である. とくに原点付近では, 式 (6), (11) より，勾配磁界 $\boldsymbol{H}_{z}^{\mathrm{g}}$ の $z$ 成分のみが抽出されて,

$$
\left\langle\boldsymbol{H}_{z}^{\mathrm{u}}, \boldsymbol{H}_{z}^{\mathrm{g}}\right\rangle \approx \frac{4}{3} H_{0}{ }^{2} \frac{z}{a}
$$

となる。そこで, 原点近傍で $z / a$ に同一視できるスカラー関数 $p_{z}(x / a, y / a, z / a)$ を,

$$
p_{z}\left(\frac{x}{a}, \frac{y}{a}, \frac{z}{a}\right)=\frac{3}{4} \frac{\left\langle\boldsymbol{H}_{z}^{\mathrm{u}}, \boldsymbol{H}_{z}^{\mathrm{g}}\right\rangle}{H_{0}^{2}}=\frac{3}{4}\left\langle\frac{\boldsymbol{H}_{z}^{\mathrm{u}}}{H_{0}}, \frac{\boldsymbol{H}_{z}^{\mathrm{g}}}{H_{0}}\right\rangle
$$

\section{で定義する}

つぎに, スカラー関数 $p_{z}(x / a, y / a, z / a)$ の值は, センサの姿 勢が未知の場合でも, 直交 3 軸磁界センサの出力により, 実測 值として評価できることを示す。直交 3 軸磁界センサに付随 する局所座標系を，直交座標系 $(\xi, \eta, \zeta)$ で表し，それぞれの座 標軸方向の単位ベクトルを $\boldsymbol{e}_{\xi}, \boldsymbol{e}_{\eta}, \boldsymbol{e}_{\zeta}$ で表すとき, 磁界 $\boldsymbol{H}_{z}^{\mathrm{u}}, \boldsymbol{H}_{z}^{\mathrm{g}}$ が,

$$
\begin{aligned}
\boldsymbol{H}_{z}^{\mathrm{u}} & =H_{z, \xi}^{\mathrm{u}} \boldsymbol{e}_{\xi}+H_{z, \eta}^{\mathrm{u}} \boldsymbol{e}_{\eta}+H_{z, \zeta}^{\mathrm{u}} \boldsymbol{e}_{\zeta} \\
\boldsymbol{H}_{z}^{\mathrm{g}} & =H_{z, \xi}^{\mathrm{g}} \boldsymbol{e}_{\xi}+H_{z, \eta}^{\mathrm{g}} \boldsymbol{e}_{\eta}+H_{z, \zeta}^{\mathrm{g}} \boldsymbol{e}_{\zeta}
\end{aligned}
$$

で表されるとする，式 (16)，(17) のベクトル成分は，直交 3 軸 磁界センサの 3 つの出力に対応している。 ベクトルの内積は座 標系に依存しないから, 式 (15) における内積 $\left\langle\boldsymbol{H}_{z}^{\mathrm{u}}, \boldsymbol{H}_{z}^{\mathrm{g}}\right\rangle$ は, 局 所座標系のベクトル成分を用いて，

$$
\left\langle\boldsymbol{H}_{z}^{\mathrm{u}}, \boldsymbol{H}_{z}^{\mathrm{g}}\right\rangle=H_{z, \xi}^{\mathrm{u}} H_{z, \xi}^{\mathrm{g}}+H_{z, \eta}^{\mathrm{u}} H_{z, \eta}^{\mathrm{g}}+H_{z, \zeta}^{\mathrm{u}} H_{z, \zeta}^{\mathrm{g}}
$$

と表される。したがって, スカラー関数 $p_{z}(x / a, y / a, z / a)$ の值 は, 直交 3 軸磁界センサの出力を用いて, センサの姿勢によら ず実測值として評価することができる.

磁界センサの位置座標 $(x, y, z)$ を推定するためには，少な くとも 3 つの測定量が必要であるから, $p_{z}(x / a, y / a, z / a)$ と同 様に，局所座標系において評価することが可能な，位置座標 $(x, y, z)$ についてのスカラー関数が，さらに少なくとも2つは 必要である.

そこでまず，Fig. 2 に示すように，正方形コイル対 $C_{x}$ を用 いて, $\boldsymbol{H}_{z}^{\mathrm{u}}$ の場合と同様に, $x$ 方向の準一様磁界 $\boldsymbol{H}_{x}^{\mathrm{u}}$ 発生させ る。 $\boldsymbol{H}_{x}^{\mathrm{u}}$ は, $\boldsymbol{H}_{z}^{\mathrm{u}}$ を $y$ 軸を中心軸として 90 度回転させた磁界で あり，ベクトル成分を用いて，

$$
\boldsymbol{H}_{x}^{\mathrm{u}}=H_{x, x}^{\mathrm{u}} \boldsymbol{e}_{x}+H_{x, y}^{\mathrm{u}} \boldsymbol{e}_{y}+H_{x, z}^{\mathrm{u}} \boldsymbol{e}_{z}
$$

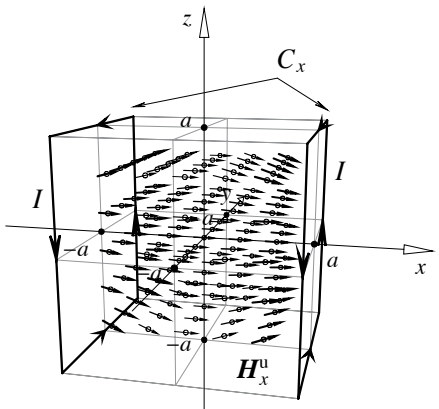

Fig. 2 The quasi-uniform magnetic field $\boldsymbol{H}_{x}^{\mathrm{u}}$ generated by a square coil pair $C_{x}$.

と表すとき，それぞれの成分の原点における Taylor 展開を 3 次の項まで示すと,

$$
\begin{aligned}
H_{x, x}^{\mathrm{u}} & =H_{0}\left(1+\frac{5}{6}\left(\frac{x}{a}\right)^{2}-\frac{5}{12}\left(\frac{y}{a}\right)^{2}-\frac{5}{12}\left(\frac{z}{a}\right)^{2}+\cdots\right) \\
H_{x, y}^{\mathrm{u}} & =H_{0}\left(-\frac{5}{6}\left(\frac{x}{a}\right)\left(\frac{y}{a}\right)+\cdots\right) \\
H_{x, z}^{\mathrm{u}} & =H_{0}\left(-\frac{5}{6}\left(\frac{z}{a}\right)\left(\frac{x}{a}\right)+\cdots\right)
\end{aligned}
$$

となる. 原点付近では

$$
\boldsymbol{H}_{x}^{\mathrm{u}} \approx H_{0} \boldsymbol{e}_{x}
$$

より, $\boldsymbol{H}_{z}^{\mathrm{g}}$ との内積は,

$$
\left\langle\boldsymbol{H}_{x}^{\mathrm{u}}, \boldsymbol{H}_{z}^{\mathrm{g}}\right\rangle \approx-\frac{2}{3} H_{0}{ }^{2} \frac{x}{a}
$$

となる．したがって，原点近傍で $x / a$ に同一視できるスカラー 関数 $p_{x}(x / a, y / a, z / a)$ は,

$$
p_{x}\left(\frac{x}{a}, \frac{y}{a}, \frac{z}{a}\right)=-\frac{3}{2} \frac{\left\langle\boldsymbol{H}_{x}^{\mathrm{u}}, \boldsymbol{H}_{z}^{\mathrm{g}}\right\rangle}{H_{0}^{2}}=-\frac{3}{2}\left\langle\frac{\boldsymbol{H}_{x}^{\mathrm{u}}}{H_{0}}, \frac{\boldsymbol{H}_{z}^{\mathrm{g}}}{H_{0}}\right\rangle
$$

で定義することができる。

つぎに，y方向については，正方形コイルを追加することな く, 磁界ベクトルの外積 (ベクトル積) により生成されるベクト 儿場を，準一様磁界の代わりに用いる. 式 (6), (23) より, $\boldsymbol{H}_{z}^{\mathrm{u}}$ と $\boldsymbol{H}_{x}^{\mathrm{u}}$ の外積 $\boldsymbol{H}_{z}^{\mathrm{u}} \times \boldsymbol{H}_{x}^{\mathrm{u}}$ は, 原点付近で $\boldsymbol{H}_{z}^{\mathrm{u}} \times \boldsymbol{H}_{x}^{\mathrm{u}} \approx H_{0}{ }^{2} \boldsymbol{e}_{y}$ であ るから，ベクトル場 $\tilde{\boldsymbol{H}}_{y}^{\mathrm{u}}$ を,

$$
\tilde{\boldsymbol{H}}_{y}^{\mathrm{u}}=\frac{\boldsymbol{H}_{z}^{\mathrm{u}} \times \boldsymbol{H}_{x}^{\mathrm{u}}}{H_{0}}
$$

で定義すれば，その分布は Fig. 3 のようになる．原点付近では 近似的に

$$
\tilde{\boldsymbol{H}}_{y}^{\mathrm{u}} \approx H_{0} \boldsymbol{e}_{y}
$$

となるから， $\boldsymbol{H}_{z}^{\mathrm{g}}$ との内積は，

$$
\left\langle\tilde{\boldsymbol{H}}_{y}^{\mathrm{u}}, \boldsymbol{H}_{z}^{\mathrm{g}}\right\rangle \approx-\frac{2}{3} H_{0}{ }^{2} \frac{y}{a}
$$

となる。したがって，原点近傍で $y / a$ に同一視できるスカラー 関数 $p_{y}(x / a, y / a, z / a)$ を,

$$
p_{y}\left(\frac{x}{a}, \frac{y}{a}, \frac{z}{a}\right)=-\frac{3}{2} \frac{\left\langle\tilde{\boldsymbol{H}}_{y}^{\mathrm{u}}, \boldsymbol{H}_{z}^{\mathrm{g}}\right\rangle}{H_{0}^{2}}=-\frac{3}{2}\left\langle\frac{\tilde{\boldsymbol{H}}_{y}^{\mathrm{u}}}{H_{0}}, \frac{\boldsymbol{H}_{z}^{\mathrm{g}}}{H_{0}}\right\rangle
$$

で定義することができる. 


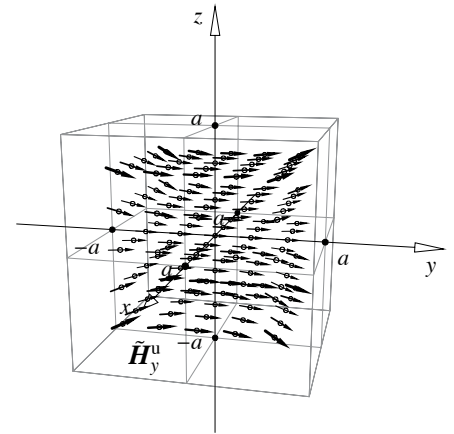

Fig. 3 The vector field $\tilde{\boldsymbol{H}}_{y}^{\mathrm{u}}$ simulating a quasi-uniform magnetic field along the $y$-axis.

\section{3 位置推定の非線形最小 2 乗問題}

磁界ベクトルの実測值から計算したスカラー関数の值から, 磁界センサの位置を推定する問題を, 非線形最小 2 乗問題と して定式化する．記述を簡略化するため, 以下では $a=1$ と する.

磁界センサがある位置 $(x, y, z)$ に, 任意の姿勢で置かれている とする。局所座標系で観測した参照磁界べクトル $\boldsymbol{H}_{x}^{\mathrm{u}}, \boldsymbol{H}_{z}^{\mathrm{u}}, \boldsymbol{H}_{z}^{\mathrm{g}}$ の実測值から， スカラー関数 $p_{x}(x, y, z), p_{y}(x, y, z), p_{z}(x, y, z)$ の 值を式 (25)，(29)，(15) により計算する。これらをスカラー関 数の実測値とみなして，それぞれ $\hat{p}_{x}, \hat{p}_{y}, \hat{p}_{z}$ で表す。このとき， 磁界センサの座標值 $x, y, z$ は, 非線形連立方程式

$$
\left.\begin{array}{l}
p_{x}(x, y, z)=\hat{p}_{x} \\
p_{y}(x, y, z)=\hat{p}_{y} \\
p_{z}(x, y, z)=\hat{p}_{z}
\end{array}\right\}
$$

の解である. $\hat{p}_{x}, \hat{p}_{y}, \hat{p}_{z}$ が誤差を含まないときには, 式 (30)に は解が必ず存在し, Newton-Raphson 法などにより数值解を求 めることができる，ただし，非線形連立方程式では一般に，解

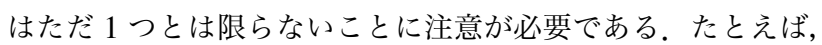
$x, y, z$ 軸上における $p_{x}, p_{y}, p_{z}$ は Fig. 4 のような值を示し, $y$ 軸 上で $p_{y}$ は単調関数ではなく,$y \approx \pm 0.6$ で極值をとる. $p_{x}$ お よび $p_{z}$ は $y$ 軸上で 0 で一定であるため, $y$ 軸上の点 $y \approx \pm 0.6$ を内部に含む領域では，座標值を一意に決定できない場合が生 じる.

実際の磁界の観測においては必ず測定誤差が生じ, $\hat{p}_{x}, \hat{p}_{y}, \hat{p}_{z}$ は誤差を含むため，式 (30) の解の存在は必ずしも保証されな
い. そのような場合でも, 式 (30) を最小 2 乗問題として解釈 すれば, Gauss-Newton 法などの数值解法を適用して，式 (30) を近似的に満足する最小 2 乗解を得ることは可能である.

式 (30) に Gauss-Newton 法を適用すると，つぎのようになる

11). 行列の転置を右肩の添字 $\mathrm{T}$ で表すとき, $\boldsymbol{X}=(x, y, z)^{\mathrm{T}}$ とお き, 式 (30)のそれぞれの方程式の残差を, $\boldsymbol{X}$ の関数 $r_{i}(\boldsymbol{X})(i=$ $1,2,3)$ として,

$$
\left.\begin{array}{l}
r_{1}(\boldsymbol{X})=p_{x}(x, y, z)-\hat{p}_{x} \\
r_{2}(\boldsymbol{X})=p_{y}(x, y, z)-\hat{p}_{y} \\
r_{3}(\boldsymbol{X})=p_{z}(x, y, z)-\hat{p}_{z}
\end{array}\right\}
$$

で定義する. $r(X)$ を残差ベクトル

$$
\boldsymbol{r}(\boldsymbol{X})=\left(r_{1}(\boldsymbol{X}), r_{2}(\boldsymbol{X}), r_{3}(\boldsymbol{X})\right)^{\mathrm{T}}
$$

とし，また，J(X)を $\boldsymbol{r}(\boldsymbol{X})$ の Jacobi 行列

$$
J(\boldsymbol{X})=\left(\begin{array}{lll}
\partial r_{1} / \partial x & \partial r_{1} / \partial y & \partial r_{1} / \partial z \\
\partial r_{2} / \partial x & \partial r_{2} / \partial y & \partial r_{2} / \partial z \\
\partial r_{3} / \partial x & \partial r_{3} / \partial y & \partial r_{3} / \partial z
\end{array}\right)
$$

とする. 残差 2 乗和 $\sum_{i=1}^{3}\left(r_{i}(\boldsymbol{X})\right)^{2}=\boldsymbol{r}(\boldsymbol{X})^{\mathrm{T}} \boldsymbol{r}(\boldsymbol{X})$ を最小化する 最小 2 乗解を数值的に求めるために, Gauss-Newton 法では適 当な初期解 $\boldsymbol{X}_{0}$ から出発して,

$$
\boldsymbol{X}_{k+1}=\boldsymbol{X}_{k}+\alpha_{k} \boldsymbol{d}_{k}
$$

により近似解を更新し, 収束解を得る。ここに, $\boldsymbol{d}_{k}$ は連立 1 次 方程式

$$
J\left(\boldsymbol{X}_{k}\right)^{\mathrm{T}} J\left(\boldsymbol{X}_{k}\right) \boldsymbol{d}_{k}=-J\left(\boldsymbol{X}_{k}\right)^{\mathrm{T}} \boldsymbol{r}\left(\boldsymbol{X}_{k}\right)
$$

の解である。また $\alpha_{k}$ は, 直線探索により反復ごとにステッ プ幅を調整するための係数で, 直線探索を省略する場合には $\alpha_{k}=1$ を用いる.

式 (35) は, $\boldsymbol{d}_{k}$ を連立 1 次方程式 $\boldsymbol{J}\left(\boldsymbol{X}_{k}\right) \boldsymbol{d}_{k}=-\boldsymbol{r}\left(\boldsymbol{X}_{k}\right)$ の最小 2 乗解として求めるときの正規方程式に相当する. $J\left(\boldsymbol{X}_{k}\right)$ の階数 が 3 であれば，そのときに限り，J( $\left.\boldsymbol{X}_{k}\right)^{\mathrm{T}} J\left(\boldsymbol{X}_{k}\right)$ の逆行列が存在 し, 式 (35) はただ 1 つの解をもつ ${ }^{12)}$. Gauss-Newton 法の反 復の過程で, $J\left(\boldsymbol{X}_{k}\right)$ に数值的な階数の低減が生じると, 式 (35) の数值解の計算は不安定となり, Gauss-Newton 法は破綻する.

スカラー関数の個数を増やして, 式 (30) の非線形連立方程式 に，さらに別の方程式を追加すれば，階数の低減がある程度抑 制されると考えられる。そのようなスカラー関数は, $p_{x}, p_{y}, p_{z}$

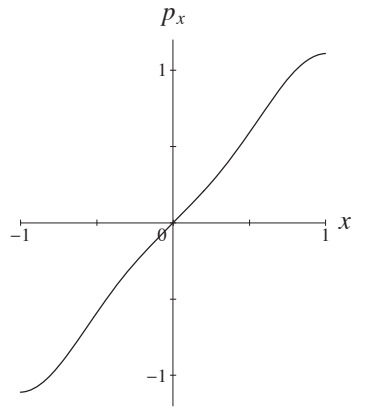

(a) $p_{x}$ on the $x$-axis

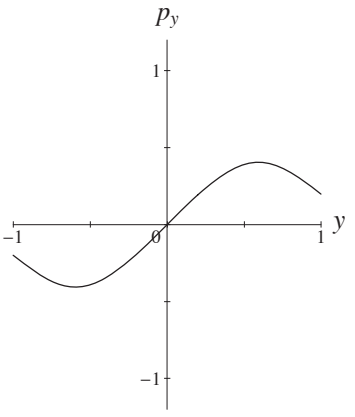

(b) $p_{y}$ on the $y$-axis

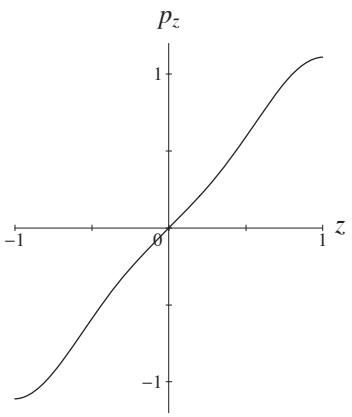

(c) $p_{z}$ on the $z$-axis

Fig. 4 Values of the scalar functions along each axis. 
と同様に, ベクトル $\boldsymbol{H}_{z}^{\mathrm{g}}, \boldsymbol{H}_{x}^{\mathrm{u}}, \tilde{\boldsymbol{H}}_{y}^{\mathrm{u}}, \boldsymbol{H}_{z}^{\mathrm{u}}$ の大きさや, 2 つのベクト ルの内積を用いて定義することができる，その具体的な一例は 4.2 項で述べる.

\section{4 位置計測のアルゴリズムとその評価}

\section{1 アルゴリズム}

2 節および 3 節で述べた位置計測の手順を整理すると次のよ うになる。

（1）正方形コイルに電流を流して準一様磁界 $\boldsymbol{H}_{x}^{\mathrm{u}}, \boldsymbol{H}_{z}^{\mathrm{u}}$ ，およ び勾配磁界 $\boldsymbol{H}_{z}^{\mathrm{g}}$ を順次, 時分割で発生し, 直交 3 軸磁界 センサにより磁界ベクトルを観測する.

（2）磁界ベクトルの実測值より式 (26) を用いて，局所座標 系で $\tilde{\boldsymbol{H}}_{y}^{\mathrm{u}}$ を計算する.

(3) 磁界ベクトルの実測值より式 (25),(29),(15) を用いて, スカラー関数值 $\hat{p}_{x}, \hat{p}_{y}, \hat{p}_{z}$ を計算する.

(4) 式 (30) の非線形連立方程式の最小 2 乗解を GaussNewton 法で計算し, 位置座標 $x, y, z$ の推定值を得る。

\section{2 位置推定のシミュレーション}

4.1 項のアルゴリズムについて, 計算機シミュレーションに より有効性を確認する。磁界センサを立方体枠の内部の適当な 位置に置いたと仮定して, 磁界ベクトルの観測を計算機上で模 擬的に再現し，アルゴリズムにしたがって決定された位置座標 が，センサの位置に一致するかどうかを試験する.

実際の計測システムでは, 磁界の測定において必ず測定䛊差 が生じる。また，計算時間の短縮のために，簡略化された近似 式など，精度を犠牲にした計算方法を用いることもありうる. しかし，ひとまずここでは，原理の有効性の確認のみに目的を 絞り, 計測および計算の過程については, つぎのように,できる だけ誤差の生じない状況を想定して, シミュレーションを実行 した，すなわち，磁界センサで測定される磁界ベクトルの測定 誤差はないものとした。 また, スカラー関数值は磁界センサの 姿勢に依存しないことから, 磁界センサの姿勢の任意性を考慮 せず，スカラー関数の実測值として，全体座標系における磁界 ベクトル成分から計算した值を用いた。また，Gauss-Newton 法の反復計算に必要な, 磁界ベクトルやスカラー関数, および Jacobi 行列は, 厳密な解析式に基づいて, すべて倍精度で計算 した.

立方体枠の内部領域の適当な点に置かれた磁界センサを想定 し，アルゴリズムにしたがって，原点座標 $\boldsymbol{X}=(0,0,0)^{\mathrm{T}}$ を初期 解として Gauss-Newton 法で反復計算を実行する。直線探索に よるステップ幅の調整はおこなわず， $\alpha_{k}=1$ とする. ただし， より多くの場合に適切な収束解が得られるよう, 途中の反復解 が立方体枠の外部に出た場合には例外として，立方体枠の表面 で止まるようにステップ幅を調節し, 反復解が常に立方体枠の 内部に収まるようにした。 反復は 30 回を上限とし, すべての 座標值 $x, y, z$ の修正量が $10^{-4}$ を下回った時点で収束解とした.

解が収束し, かつ許容誤差の範囲内で真值に一致した場合に は, 座標值の推定が成功したと判定する。ここで許容誤差は, 座標值 $x, y, z$ の真值からのずれがすべて $10^{-4}$ 以下とした，反 復回数の上限までで解が収束しなかった場合や, 真值とは異な
る解に収束した場合のほかに, Jacobi 行列が数值的に特異とみ なされり, 演算の過程でオーバーフローが発生するなどして, 計算が続行できなくなった場合はすべて，推定に失敗したと判 定する.

Fig. 5 は, 3 つのスカラー関数 $p_{x}, p_{y}, p_{z}$ を用いた場合につい て, $z=0.2 k(k=0,1, \ldots, 5)$ のそれぞれの平面上で, ランダ ムに発生した 2000 個の位置座標を，アルゴリズムにしたがつ て推定する計算機シミュレーションを実行した結果を示して いる. 対称性を考慮して, 計算は $x \geq 0, y \geq 0$ の $1 / 4$ 領域のみ で実行した．図では，領域を一辺の長さが 0.05 の正方形のブ ロックに区切り，ある1つのブロックに含まれるすべての計 算点において, 許容誤差の範囲内で真の座標值に収束した場合 には，そのブロックにハッチング模様を記した。ハッチングの 濃淡は, 収束に要した反復回数の最大值に対応し, 濃いブロッ クほど，少ない反復回数で推定できたことを示している。ま た，真值とは異なる解に収束した点を含むブロックには三角 $(\triangle)$ を記し，その他の，収束に失敗した点を含むブロックには バッ $(\times)$ を記した。真の座標值への収束に成功した領域の大部 分が, 反復 10 回以内で収束している一方で, 反復回数の上限 を 20 回から 30 回に引き上げて収束解が得られた領域はわず かである。バツ $(\times)$ の領域では, Jacobi 行列が特異に近いか, あるいはスカラー関数の強い非線形性のために, 収束が悪化し ていると考えられるが, さらなる反復回数の増加により, これ らの領域で容易に収束解が得られるとは考えにくい. また， 3 節で $y$ 軸上における例を示したように，真の座標値と同一のス カラー関数值を与える別の座標值が存在する場合には, 座標值 は一意に決定することができない，そのため，Gauss-Newton 法の収束解は初期解に依存し, 三角 $(\Delta)$ で示された, 真の座標 值以外に収束する領域が生じる。前述の $y$ 軸上における $p_{y}$ の 非単調性を直接に反映して, $y$ 軸付近では $|y| \leq 0.6$ の領域での み真の座標値が得られている。

座標が正しく推定された領域の形状は複雑であるが，実用的 な計測領域は，単純な形状のひとつながりの領域とすべきであ る. そこで，本論文では計測可能な領域を，原点を中心とする 直方体領域として評価する．Fig. 5 より，図に破線で示したよ うに, おおよそ $|x| \leq 0.7,|y| \leq 0.6,|z| \leq 0.6$ の立方体領域の内部 で, 反復 20 回以内で位置の推定が可能となっている.

つぎに，スカラー関数の個数を増やしたときに，計測可能な 領域が広がるかどうかを検証する。ここでは新たに，べクトル $\boldsymbol{H}_{x}^{\mathrm{u}}, \tilde{\boldsymbol{H}}_{y}^{\mathrm{u}}, \boldsymbol{H}_{z}^{\mathrm{u}}$ のそれぞれの大きさの 2 乗に比例するスカラー関 数 $h_{x}^{2}, h_{y}^{2}, h_{z}^{2}$ を,

$$
\begin{aligned}
& h_{x}^{2}\left(\frac{x}{a}, \frac{y}{a}, \frac{z}{a}\right)=\frac{\left|\boldsymbol{H}_{x}^{\mathrm{u}}\right|^{2}}{H_{0}^{2}}=\left\langle\frac{\boldsymbol{H}_{x}^{\mathrm{u}}}{H_{0}}, \frac{\boldsymbol{H}_{x}^{\mathrm{u}}}{H_{0}}\right\rangle \\
& h_{y}^{2}\left(\frac{x}{a}, \frac{y}{a}, \frac{z}{a}\right)=\frac{\left|\tilde{\boldsymbol{H}}_{y}^{\mathrm{u}}\right|^{2}}{H_{0}^{2}}=\left\langle\frac{\tilde{\boldsymbol{H}}_{y}^{\mathrm{u}}}{H_{0}}, \frac{\tilde{\boldsymbol{H}}_{y}^{\mathrm{u}}}{H_{0}}\right\rangle \\
& h_{z}^{2}\left(\frac{x}{a}, \frac{y}{a}, \frac{z}{a}\right)=\frac{\left|\boldsymbol{H}_{z}^{\mathrm{u}}\right|^{2}}{H_{0}^{2}}=\left\langle\frac{\boldsymbol{H}_{z}^{\mathrm{u}}}{H_{0}}, \frac{\boldsymbol{H}_{z}^{\mathrm{u}}}{H_{0}}\right\rangle
\end{aligned}
$$

で定義する。これらを加えた 6 つのスカラー関数 $p_{x}, p_{y}, p_{z}$, $h_{x}^{2}, h_{y}^{2}, h_{z}^{2}$ について, 同様のシミュレーションを実行した結果を Fig. 6 に示す。計測可能な領域は，図に破線で示したように， 
おおよそ $|x| \leq 0.8,|y| \leq 0.7,|z| \leq 0.6$ と見積もられる．すなわ ち, 3 つのスカラー関数 $p_{x}, p_{y}, p_{z}$ を用いて得られた計測領域 に加え, スカラー関数 $h_{x}^{2}, h_{y}^{2}, h_{z}^{2}$ の追加により, $x$ 方向および $y$
方向にはさらに広い計測領域が得られている. Fig. 5 において 三角 $(\triangle)$ の記された領域，およびバッ $(\times)$ の記された領域は，

Fig. 6 においてはいずれも縮小しており, より広い領域で, 座

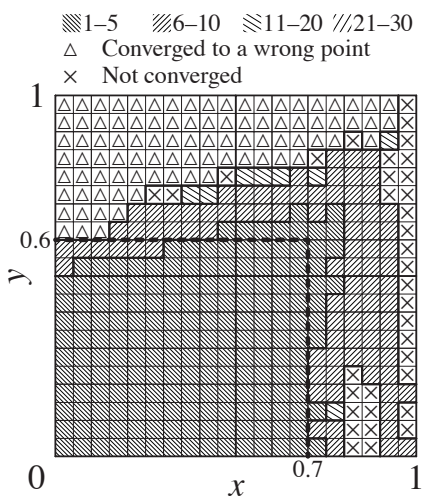

(a) $z=0$

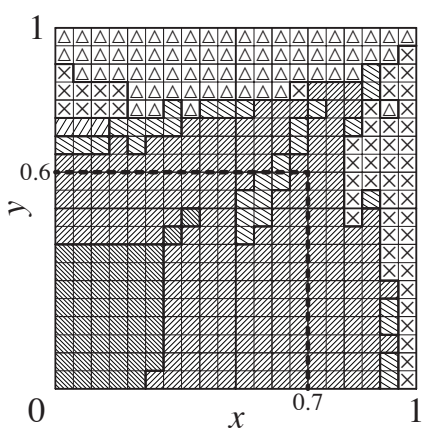

(d) $z=0.6$

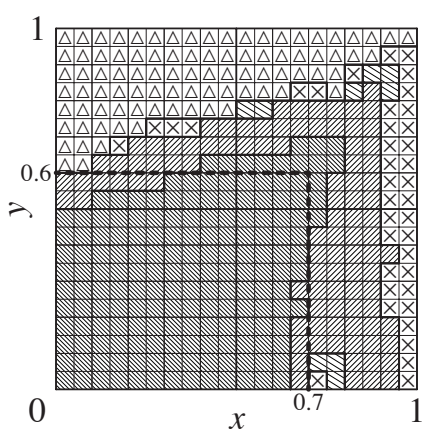

(b) $z=0.2$

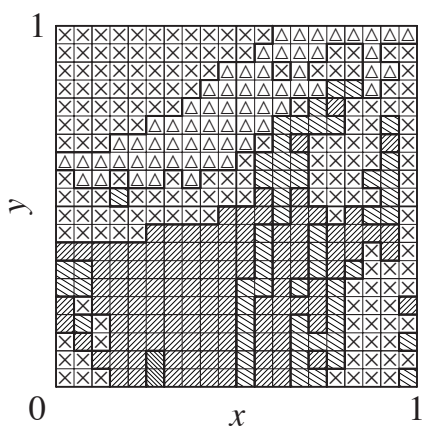

(e) $z=0.8$

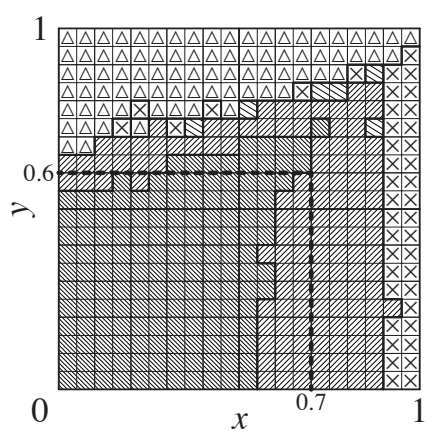

(c) $z=0.4$

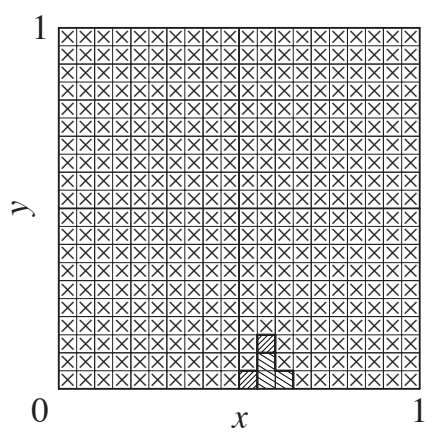

(f) $z=1$

Fig. 5 The region in which the position can be determined by the algorithm from the three scalar functions $p_{x}, p_{y}, p_{z}$.

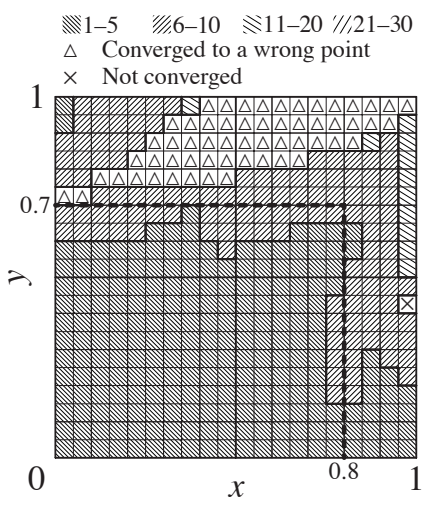

(a) $z=0$

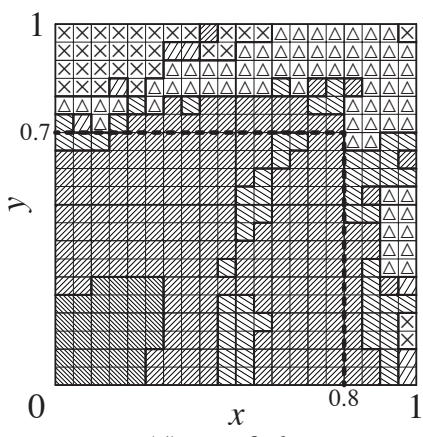

(d) $z=0.6$

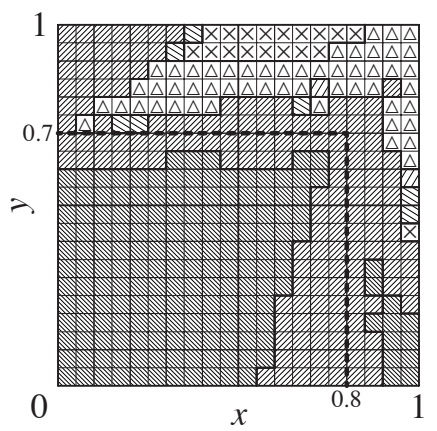

(b) $z=0.2$

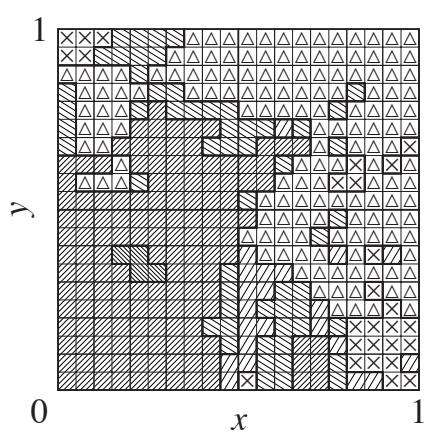

(e) $z=0.8$

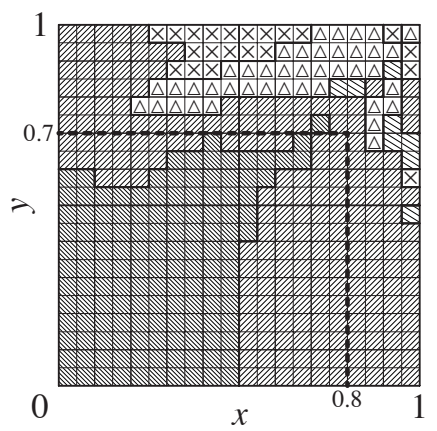

(c) $z=0.4$

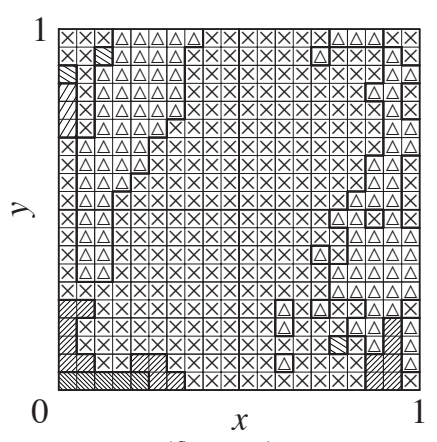

(f) $z=1$

Fig. 6 The region in which the position can be determined by the algorithm from the six scalar functions $p_{x}, p_{y}, p_{z}, h_{x}^{2}, h_{y}^{2}, h_{z}^{2}$. 


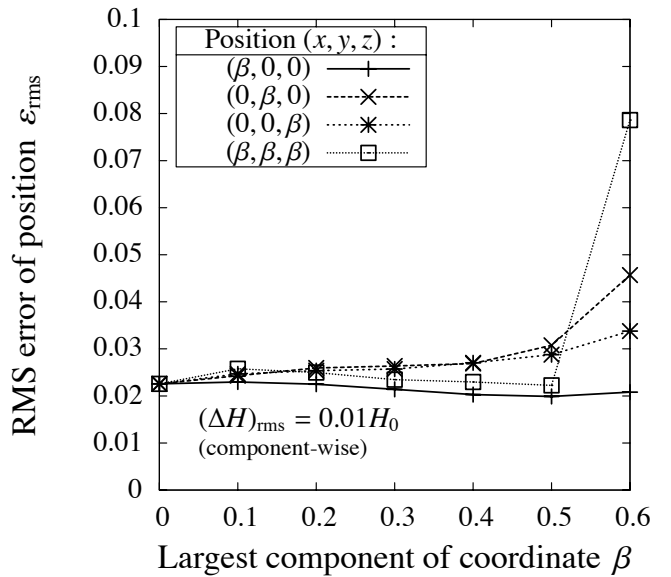

Fig. 7 Positional errors when using the six scalar functions $p_{x}, p_{y}, p_{z}, h_{x}^{2}, h_{y}^{2}, h_{z}^{2}$ estimated by a Monte Carlo simulation assuming small measurement errors in the magnetic fields.

標値の一意性が確保され, あるいはまた, Jacobi 行列の階数の 低下が抑制されたと考えられる。

\section{3 磁界の測定誤差の影響の評価}

磁界センサの出力に誤差がある場合に, 位置座標の推定にど のような影響が出るかを, モンテカルロ法を用いた計算機シ ミュレーションにより見積もる。

ある位置で計算された磁界ベクトル成分のそれぞれに，測定 誤差に相当する数值を加えて磁界の測定值を模擬し，これを 用いて推定された位置と真の位置との距離を，位置の推定誤 差として評価する.ここでは測定䛊差として, 平均值 0 , 標準 偏差 $0.01 H_{0}$ の正規乱数を用い，ある 1 つの位置座標に対する 2000 回の試行について, 推定䛊差の二乗平均平方根 (RMS) を 計算し，その位置における推定誤差の見積もりとした６つの スカラー関数 $p_{x}, p_{y}, p_{z}, h_{x}^{2}, h_{y}^{2}, h_{z}^{2}$ を用いた場合について, $a=1$ として, $x, y, z$ 軸上および立方体枠の対角線上の点で, このシ ミュレーションを実行し, 位置の推定誤差を評価した結果を Fig. 7 に示す. $x, y, z$ それぞれの絶対值の中の最大值を $\beta$ で表 すとき, $\beta \leq 0.5$ の領域では, 磁界の測定誤差による位置の推定 誤差は，およそ 0.02 から 0.03 までの間で大きな変動はなく, $\beta=0.6$ においても誤差は, 最大で原点の 4 倍程度に収まる.

Sasada and Morimoto のシステムで，実測により見積もら れた位置の推定誤差 7) を, 本項での評価方法に換算すると, $\beta \leq 0.4$ の領域で 0.02 前後となる. かりに本方法において, 磁 界ベクトル成分の測定誤差を $0.01 H_{0}$ 程度に抑えることができ れば, $\beta \leq 0.5$ の領域で, かれらのシステムとほぼ同程度の精 度が実現できると考えられる。

\section{5 まとめ}

本論文では, 3 次元空間において, 立方体形状の枠に配置さ れた 4 個の正方形コイルによる参照磁界と, 物体に取り付けら れた直交 3 軸磁界センサを用いて物体の位置を決定する, 磁気 式モーションキャプチャの新しい方式について述べた.

磁界ベクトルの内積を用いて定義されたスカラー関数が, 位 置座標の関数であることを利用して, 位置座標の推定問題を非
線形最小 2 乗問題として定式化したのち, Gauss-Newton 法を 用いた数值計算により位置座標を決定するアルゴリズムを提示 し，その有効性を検証した。

まず，磁界ベクトルの計測誤差がない状況を想定した計算 機シミュレーションにより，原理的には，3つ以上のスカラー 関数を用いて, 正方形コイルの配置された立方体枠の中心部 に，立方体枠の少なくとも約 6 割の辺長をもつ立方体領域を 含む計測領域を確保できることを示した。つぎに，スカラー関 数を 6 つに増やした場合について, 座標值の一意性の確保や, Gauss-Newton 法の破綻の抑制などの効果により，さらに広い 計測領域が得られることを示すとともに，モンテカルロ法を用 いた計算機シミュレーションにより, 磁界ベクトルの測定值が 誤差を含む場合にも，立方体枠の 6 割の辺長をもつ立方体領域 において，安定した位置の推定が可能である見通しを示した．

Sasada and Morimoto の方式では 6 個必要であった正方形コ イルを，本方式では 4 個に減らすことにより，モーションキャ プチャ装置の構成が簡素化されるだけでなく，物体や人体の移 動を妨げる障害物が少なくなり，装置の利便性は向上する。そ の一方で，十分な大きさの計測領域を確保するために，本論文 では位置座標の推定を非線形最小 2 乗問題として定式化し，そ の解法として, 計算量の多い Gauss-Newton 法を用いている. 結果として本方式は, Sasada and Morimoto の方式に比べて, 装置の構成はより簡単で, 計測領域はより広くなったが，位置 座標の推定に必要な計算量は大幅に増えている. 本方式の利点 を最大限に生かした，実用的なモーションキャプチャシステム を実現するためには，計算量の大幅な削減が必要である。その ために，著者らは現在，Gauss-Newton 法のような反復計算を 必要とせず，スカラー関数の測定值のみから直接に座標値を計 算する方法について，研究を進めている.

\section{References}

1) K. Aminian and B. Najafi: Comput. Animat. Virtual Worlds, 15, 79 (2004).

2) J. G. Richards: Hum. Mov. Sci., 18, 589 (1999).

3) F. H. Raab, E. B. Blood, T. O. Steiner, and H. R. Jones: IEEE Trans. Aerosp. Electron. Syst., 15, 709 (1979).

4) O. Atoda, Y. Nakamura, M. Tomisawa, K. Yokoyama, and T. Imada: Trans. SICE, 34, 445 (1998) (in Japanese).

5) H. P. Kalmus: IRE Trans. Aerosp. Navig. Electron., 9, 7 (1962).

6) E. Paperno, I. Sasada, and E. Leonovich: IEEE Trans. Magn., 37, 1938 (2001).

7) I. Sasada and H. Morimoto: Tech. on Magnetics, IEE Japan, MAG98-226 (1998) (in Japanese)

8) I. Sasada and H. Morimoto: Dig. of INTERMAG 99, Kyongju, 1999, BS-11 (The IEEE magnetics society, 1999).

9) M. Kumagai and T. Emura: Proc. SICE 2002, Osaka, 2002, p. 3112 (The Society of Instrument and Control Engineers, 2002).

10) N. Iwahori: Bekutoru Kaiseki (in Japanese), p. 28 (Shōkabō, Tokyo, 1960).

11) H. Yabe and N. Yamaki: Hisenkei Keikakuhō (in Japanese), pp. 95-96 (Asakura Shoten, Tokyo, 1999).

12) G. Strang (M. Yamaguti, and A. Inoue): Senkeidaisū to sono Ōyō (Linear Algebra and its Applications) (in Japanese), p. 126 (Sangyōtosho, Tokyo, 1978).

2007 年 2 月 5 日受理, 2007 年 9 月 20 日再受理, 2007 年 10 月 19 日採録 